\title{
Environmental Analysis of Arsenic in Water, Soil and Food Materials from Highly Contaminated Area of Alampur Village, Amjhupi Union, Meherpur
}

\author{
Tanvir Ahsan Haquea, Maliha Tabassuma, Md Jamilur Rahmana, (D), Mohd Nur E Alam Siddiqueb,* (iD, \\ Md Golam Mostafab, Md Abdul Khalaque ${ }^{a}$, Zainal Abedinea , Hoda Hamidic, iD \\ a Department of Environmental Science, School of Environmental Science and Management, Independent University,
Dhaka, Bangladesh
${ }^{b}$ Analysis and Development Division, Global Environment Consultant Limited, Dhaka, Bangladesh
${ }^{c}$ Department of Chemistry, Payame Noor University (PNU), P.O BOX 19395-4697, Tehran, Iran
}

\section{ART ICLE INF O}

Received: 28 May 2019

Revised: 16 July 2019

Accepted: 19 August 2019

Available online: 23 August 2019

\section{K E Y W O R D S}

\section{Arsenic}

Groundwater

Meherpur

Ag-DDTC

Soil

Vegetables

\begin{abstract}
A B S T RAC T
Bangladesh is a riverine country where arsenic bearing silt and sediments coming from Himalayas gets deposited in the groundwater aquifers at different locations of Bangladesh. Groundwater is the most dependent form of sources for drinking in this area, unfortunately arsenic is of extensive amount (more than $50 \mathrm{ppb}$ ) found in this groundwater. Fourteen water samples from different depth of tube well, 8 soil samples from topsoil $(15 \mathrm{~cm})$ and subsurface $(30 \mathrm{~cm})$ and 7 different types of food materials were collected from Alampur Village, Amjhupi Union at Megerpur district. Water samples are preserved by $\mathrm{HNO}_{3}$ for maintaining $\mathrm{pH}$ (2-3). Food and food materials were digested with $\mathrm{HNO}_{3}-\mathrm{H}_{2} \mathrm{SO}_{4}$ in order to determine the arsenic by Ag-DDTC, UV-visible method. The arsenic of tube well water was beyond the Bangladesh acceptable limit and arsenic in food materials were with the limit of Australian food hygiene limit (1 mg / kg). Concentration of arsenic in topsoil $(15 \mathrm{~cm})$ was higher than arsenic in the subsurface $(30 \mathrm{~cm})$. The values of arsenic in food materials was lower, which indicated that arsenic from tube well water is adsorbed in soil but not to propagate food materials. It might be due to the type of soil.
\end{abstract}

\section{G R A P H I C A L A B S T R A C T}

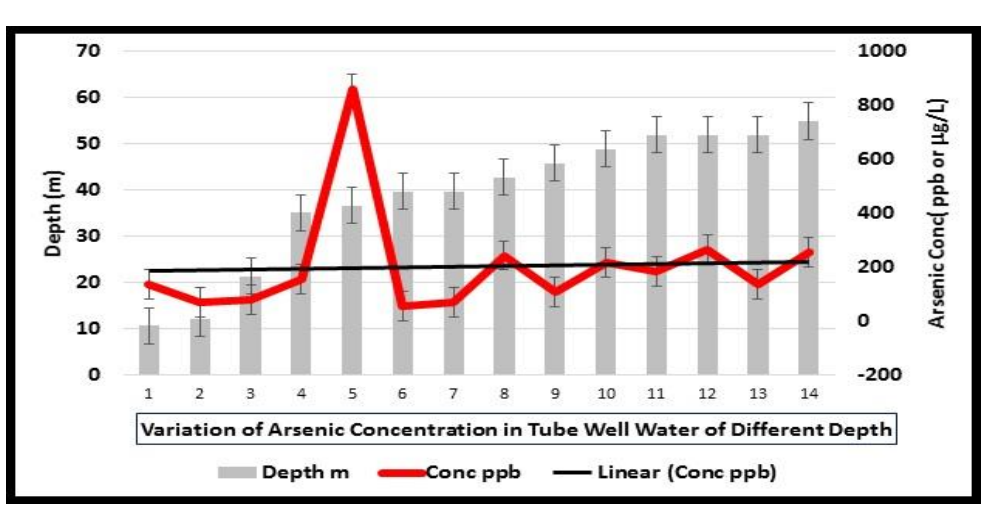

* Corresponding author's E-mail address: nasiddique75@yahoo.com 


\section{Introduction}

In Bangladesh, the arsenic affected areas are near the banks of major river systems [1]. Being a river delta and having a tropical monsoon climate the rivers change their paths with time and form tributaries. This causes vulnerability of flooding of vast land areas during the period of high discharge. Due to current of rivers, can cause bank erosion [2]. Erosion also plays a major part in the flow change of the rivers. Naturally sediments flow with the currents of water coming from the mountain ranges of Himalayas, prompting the buildup of sediment faster than the rivers can wash it away. Resultantly, sedimentation places disparate types of minerals on the adjacent lands, arsenic being one of those and it is found in many parts of the floodplain [3].

Arsenic is found in groundwater due to exposure to aquifer matrix containing iron oxides and pyrites. In this context, the tubewell water of Chapai-Nawabgonj and Kustia, Meharpur, Pabna, Faridpur, Manikgong and Chandpur are near-side districts of the Ganges or Padma River. These above districts are mostly affected by arsenic [4]. Arsenopyrite (FeAsS) arsenic bearing mineral, but with the advent of intensive irrigation in the 1960s, the aquifer has dropped and water has been replaced by oxygen in those layers. As a result, arsenopyrite oxidized in the presence of oxygen and water and form hydrated compound. Arsenopyrite, once oxidized, becomes water soluble and seep like drops of tea from the teabag. They percolate from the subsoil into the roping water tables in every monsoon. As monsoon replenished the water table, the arsenic seeped into the tube well [5]. Although the mechanism of arsenic release from the sediments is unknown, Stute et al. (2007) suggested that the kinetics of arsenic release from the sediments and the groundwater residence time was an important factor. However, arsenic has probably been presented in the groundwater for thousands of years [6]. Still the hilly areas and certain districts [Naogoan, Dinajpur and hilly areas] of Bangladesh are not contaminated by arsenic in groundwater [7]. The Padma, Jumuna and Meghna rivers are far away from the above-mentioned areas. It would be proven that, areas of river banks are most affected groundwater by the arsenic. In Bihar, Ground water in 13 districts has been found to be contaminated with arsenic with quantities exceeding $0.05 \mathrm{mg} / \mathrm{L}$ (50 ppb). All these districts are situated close to large rivers like Ganga and Gandak [8]. Groundwater in the majority of deep tubewells have concentrations of arsenic exceeding the World Health Organization's limit of $10 \mathrm{ppb}$, and only $30 \%$ of groundwater contains arsenic at levels below $50 \mathrm{ppb}$, the Bangladesh drinking-water standard [9]. There are three main types of arsenic in nature: airborne, inorganic, and organic. Two key areas are the interaction of trivalent arsenicals with sulfur in proteins and the ability of arsenic to generate oxidative stress [10].

Different sources of arsenic produce different forms of arsenic. Inorganic arsenic typically originates from geological sources, such as bedrock [11], and leaches into ground water. Therefore, inorganic arsenic is of greatest concern for drinking water. Arsenic can be found in any type of bedrock [12]. More than $80 \%$ of the population depends on agriculture for their livelihood. Now-a-days, $90 \%$ of Bangladeshi depends on ground water for drinking purpose because much of surface water of Bangladesh is microbial unsafe to drink. Arsenic exists in the form of arsenic (V) in surface waters, and arsenic (III) in ground waters. Arsenic contamination in the ground water of Bangle-delta (Bangladesh and West Bengal, India) region was first discovered in 1980 's in the West Bengal of India. The scientists of West Bengal urged Bangladesh to test the level of arsenic in Bangladesh as both the regions (Bangladesh and West Bengal, 
India) are situated in the Bengal-delta. In 1993, the Department of Public Health Engineering first identified the presence of arsenic in well-water in three districts (Chapai-Nawabgonj) in the northwest region of Bangladesh. The concentrations of arsenic in non-contaminated soils range from 0.1 to $10 \mathrm{mg} / \mathrm{Kg}$. However, the arsenic content in some parts of Bangladesh soils are more than $30 \mathrm{mg} / \mathrm{kg}$ [13]. Much of Bangladesh aquifer system is characterized by a two-aquifer system. A shallow aquifer typically extending from $10 \mathrm{~m}$ to $70 \mathrm{~m}$ below ground level, and a deeper aquifer below about $200 \mathrm{~m}$. A surface layer of silty clay forms a semi-confining layer and a lower clay layer (as thick as $30 \mathrm{~m}$ ) sometimes separates the shallow and deep aquifers or may not be present at all (BGS and DPHE, 2001). Horneman et al. (2004) studied the interface between reduced and oxidized aquifers drops from a depth of $30 \mathrm{~m}$ to $150 \mathrm{~m}$ within a few kilometers in the east of Dhaka. In most of the southern Bangladesh, the situation is much more complex with a division of the shallow aquifer into two by a low permeability silt-clay layer (Harvey et al., 2006; JICA, 2002). The shallow (or main) aquifer has been extensively exploited and is the source of arsenic problem (Jakariya and Bhattacharya, 2007). Groundwater from depths of more than 150-200 m appears to be essentially arsenic-free. The top of the shallow aquifer, at depths of less than $10 \mathrm{~m}$, also appears to be less contaminated than deeper down and may account in part for observation that shallow hand-dug wells are usually uncontaminated even in areas of otherwise high arsenic contamination (Green et al., 2005; Jakariya and Bhattacharya, 2007) [ 6]. Arsenic is a widely-dispersed element in the Earth's crust and exists at an average concentration of approximately $5 \mathrm{mg} / \mathrm{kg}$ [14]. Arsenic occurs as a constituent in more than 200 minerals, although it primarily exists as arsenopyrite and as a constituent in several other sulfide minerals [15]. Most of the arsenic added to paddy soils from irrigation water remains in the topsoil, and the amounts leached to the subsoil or groundwater appear to be small in Bangladesh. In a survey of 270 STWS distributed more or less evenly across Bangladesh. Mean concentration in topsoil (0$15 \mathrm{~cm}$ ) were generally higher than subsurface layer (30 cm depth), and significantly higher in irrigated soils than in non-irrigated soil [16]. The form and behavior of arsenic vary greatly between flooded soil and non-flooded soils. The most important arsenic species are arsenate (V) under non-flooded conditions and arsenite (III) under flooded conditions. Arsenic (III) has a higher solubility than Araenic (V), resulting in a higher mobility of arsenic in flooded soils. Soil texture is another important factor, with clay soils having a much greater capacity to bind arsenic than sandy soils [14]. On average, a Bangladeshi adult drinks about 4 to $5 \mathrm{~L}$ of water a day and consumes about $450 \mathrm{~g}$ of rice. Assuming 200 ppb arsenic in the drinking water and about $0.5 \mathrm{mg} / \mathrm{kg}$ in rice grain, the total daily intake of arsenic would be around $1.2 \mathrm{mg}$, which may not be safe for human [17]. The maximum allowable daily level of arsenic in foodstuff is taken as $0.22 \mathrm{mg}$. Calculations were made based on the possibility of exceeding this maximum allowable daily level (MADL) for various plants analyzed. For example, a person who consumes $100 \mathrm{~g}$ of arum that contains $2.2 \mathrm{mg} / \mathrm{kg}$ of arsenic daily would have an MADL from arum alone. However, when the concentration of arsenic is as high as $22 \mathrm{mg} / \mathrm{kg}$, only $10 \mathrm{~g}$ would give the MADL. Similarly, $440 \mathrm{~g}$ of rice with $0.5 \mathrm{mg} / \mathrm{kg}$ of arsenic would also represent the MADL. Such inputs are comparable to drinking $4.4 \mathrm{~L}$ of water with $0.05 \mathrm{mg} / \mathrm{L}$ of arsenic. The authors also analyzed some cooked foods for their arsenic content. These were collected from households who used arsenic-contaminated water for cooking [8-18]. In an attempt to assess the extent of diversification of the ground water arsenic, the levels of arsenic in 
common vegetables, spinach and fish consumed by man were investigated. Among the vegetables mean arsenic concentrations in potatoes (Solanum tuberosum) and pointed gourd/potals (Trichosanthes dioeca) were 0.598 and $0.10 \mathrm{ppm}$ FW, respectively and were higher than the values for those grown on untreated or uncontaminated soils, as reported in literature (Nriagu, 1994). In spinach, significant levels of arsenic in arum/kachu (Colocasiaantiquorum) and water spinach/kalmi sak (Ipomoea reptans) were found (range: 0.11-3.49 ppm FW, $\mathrm{n}=5$ ) and (range: 0.09-2.03 ppm FW, $\mathrm{n}=5$ ) respectively. Arsenic concentrations in balsam apple/korola (Momordicacharantia), ladies finger/derosh (Hibiscus esculentus), and Jute (Corchorus capsularis) leaves were not significant [19].

The aim of study is to provide an overview of the latest findings of arsenic contamination in groundwater, soil and food materials and the subsequent transfer of arsenic via water/soil to cropsat Alampur village, Amjhupi Union under Meharpur Distract.

\section{Experimental}

Site selection

Figure1. Study area map of Alampur village, Amjhupi Union, Meherpur District with sample locations
Alampur Village, Amjhupi Union, Meherpur Sadar Upazila, Meherpur District, Bangladesh. The Village Alampur is approximately 8-10 km away from the main Meherpur district town. It contains near about 100 households and most households are suffering from arsenic contamination on different levels of exposure.

\section{Sample collection}

Water, soil and vegetable samples were collected from Alampur village in Meherpur district for the determination of arsenic. A total of fourteen water samples were collected from tube well of different depths. Thetube well water samples were preserved with $\mathrm{HNO}_{3}$ and kept $\mathrm{pH}$ of the water samples within pH range 2 to 3 [20]. Sample were stored (4 ${ }^{\circ} \mathrm{C}$ ) in refrigerator before analysis. At the same time, eight vegetables and eight soil samples were collected as well. Soil samples were collected in two layers; top soil (15 cm depth) and subsurface layer (30 $\mathrm{cm}$ depth). The location of the samples was noted using Garmin GPS device in order to locate the samples and present them on a map. The map was created using ESRI ArcMap 10.3. The map is affixed below.

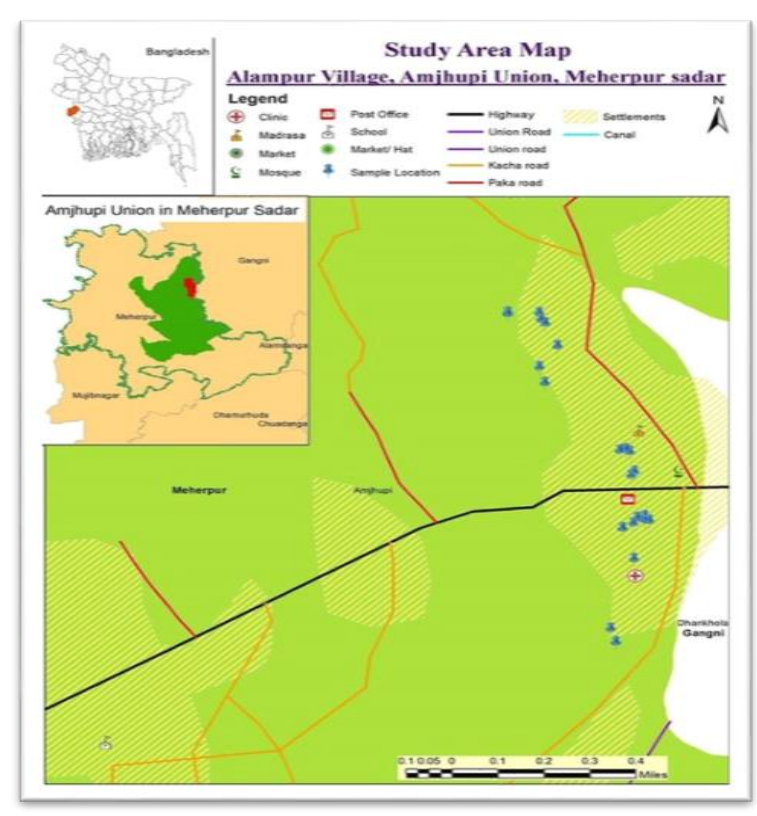


Principle of the method

Necessary reagents needed for the determination process were:

- Silver Diethyldithiocarbamate (Ag-DDTC) Ag-SCSN $\left(\mathrm{C}_{2} \mathrm{H}_{5}\right)_{2}$

- 1:1 Hydrochloric acid

- $10 \%$ stannous chloride

- $15 \%$ potassium iodide

- $10 \%$ nickel chloride

- Zinc Powder

- $10 \%$ Lead acetate

Inorganic arsenic is reduced to arsine, $\left(\mathrm{AsH}_{3}\right)$, by zinc in acid solution ( $\mathrm{HCl}$ ) in a Gutzeit generation (modified). The arsine is then passed through a scrubber containing glass wool impregnated with lead acetate solution and into an absorber tube containing Ag-DDTC dissolved in chloroform. In the absorber arsenic reacts with the silver salt, forming a soluble red complex suitable for photometric measurement at 540 nm. $0.75 \mathrm{~g}$ of Ag-DDTC in a solution of $1 \mathrm{~mL}$ of morpholine dissolved in $100 \mathrm{~mL}$ of chloroform $\left(\mathrm{CHCl}_{3}\right)$. Then it was kept in a round bottom quick fitted flask covering with aluminum foil and preserved at $4^{\circ} \mathrm{C}$ in a refrigerator. $15 \mathrm{~g}$ potassium Iodide (KI) was dissolved in $100 \mathrm{~mL}$ distilled deionized water. $10 \mathrm{~g}$ stannous chloride $\left(\mathrm{SnCl}_{2} \cdot 2 \mathrm{H}_{2} \mathrm{O}\right)$ and $10 \mathrm{~g}$ nickel nitrate $\left[\mathrm{Ni}\left(\mathrm{NO}_{3}\right)_{2}\right.$.

Figure 2. Calibration curve absorbance verses concentration of arsenic

Figure 3. Arsine gas generator cell (Gutzeitcell)
$6 \mathrm{H}_{2} \mathrm{O}$ ] were dissolved in $100 \mathrm{~mL}$ distilled deionized water respectively. $50 \mathrm{~mL}$ sample was taken into a clean generator bottle (quick fitted $100 \mathrm{~mL}$ conical flask) adding successively, $5 \mathrm{~mL}$ 1:1 HCl, $5 \mathrm{~mL} \mathrm{KI} \mathrm{(15 \% )} \mathrm{solution} \mathrm{and} 8 \mathrm{drops}^{\mathrm{SnCl}} 2$ reagent. Adding $1 \mathrm{~g}$ Zn-dust to generator, it was connected with scrubber absorber, immediately. All connection must be fitted tightly. Allowing 20 min, for complete evolution of arsine and pouring solution absorber into a $1 \mathrm{~cm}$ cell, the absorbance was measured at $540 \mathrm{~nm}$, using the reagent blank as the reference [20].

\section{Preparation of the calibration curve}

Standard calibration curve was prepared through blank samples and synthesized arsenic samples of $100 \mathrm{ppb}$ to $25 \mathrm{ppb}$ of which the absorbance was noted in line with the concentration of the solutions. The correspondence was built upon the findings. In order to consolidate the standard, curve the 100ppbarsenic sample was repeatedly measured for absorbance. However, the absorbance varied on several occasions, so to fulfill the purpose a specific point was taken into account for the determination. The blank sample was $0.75 \% \mathrm{Ag}$ DDTC salt solution of morpholine or chloroform, which acted as the absorber in the process.
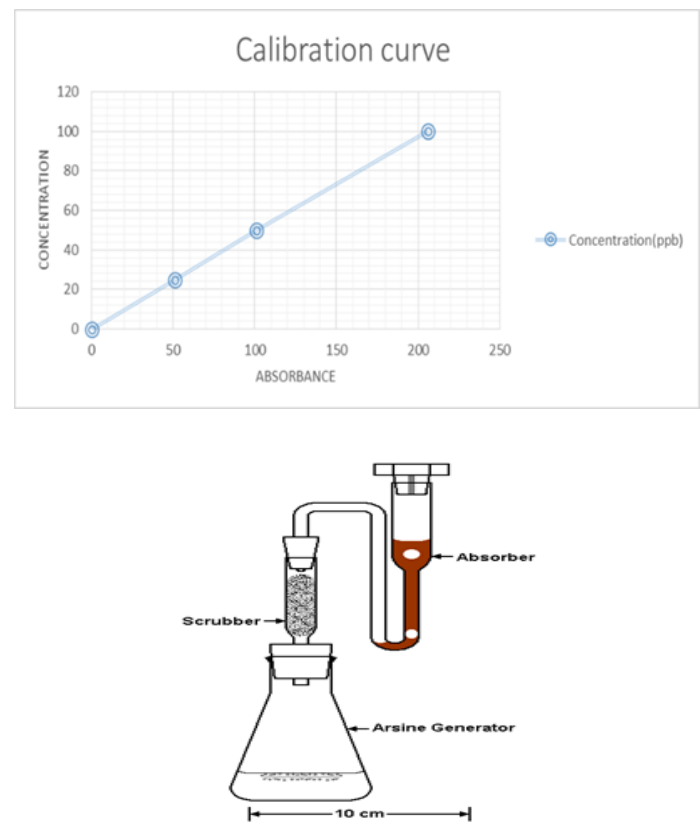


\section{Results and Discussion}

14 tube well waters (Table 1) are collected from Alampur village at Meharpur district, all groundwater of tube well is contaminated with arsenic ( $>50 \mathrm{ppb})$. The level of arsenic in ground water is higher the level of arsenic as per the standard limit of Bangladesh as well as WHO. The concentration of arsenic varied from $54 \mathrm{ppb}$ to $869 \mathrm{ppb}$ for different depths (10.66 $\mathrm{m}$ to $54.86 \mathrm{~m}$ ) of the tube wells.

The value of correlation coefficient $\left(R^{2}=0.0035\right)$ is very much less than 1 , it indicated that, arsenic concentration of different depth has poor relation. The concentration of arsenic in different depth depends on the geology and geochemical transformation of arsenic in different depth (m).

Natural levels of arsenic in soil usually range from 1 to $40 \mathrm{mg} / \mathrm{kg}$. The concentration of arsenic (Table 2) is varied from 1.175 $\mathrm{mg} / \mathrm{Kg}$ to $5.69 \mathrm{mg} / \mathrm{Kg}$ at $15 \mathrm{~cm}$ depth and $0.1865 \mathrm{mg} / \mathrm{Kg}$ to $3.0035 \mathrm{mg} / \mathrm{Kg}$ at $30 \mathrm{~cm}$ depth of Alampur village.

Table 1. The concentration of arsenic in water at different depth of tube wells in Alampur village

\begin{tabular}{ccc} 
Serial Number & Depth $(\mathrm{m})$ & Concentration of arsenic $(\mathrm{ppb})$ \\
1 & 10.66 & 136.44 \\
2 & 12.19 & 69.15 \\
3 & 21.33 & 77.57 \\
4 & 35.05 & 156.70 \\
5 & 36.57 & 859.81 \\
6 & 39.62 & 54.14 \\
7 & 39.62 & 71.02 \\
8 & 42.67 & 242.99 \\
9 & 45.72 & 106.54 \\
10 & 48.76 & 218.69 \\
11 & 51.81 & 184.53 \\
12 & 51.81 & 265.42 \\
13 & 51.81 & 136.44 \\
14 & 54.86 & 256.07 \\
\hline
\end{tabular}

Figure 4. Variation of arsenic concentration in tubewell water at different depth (m)

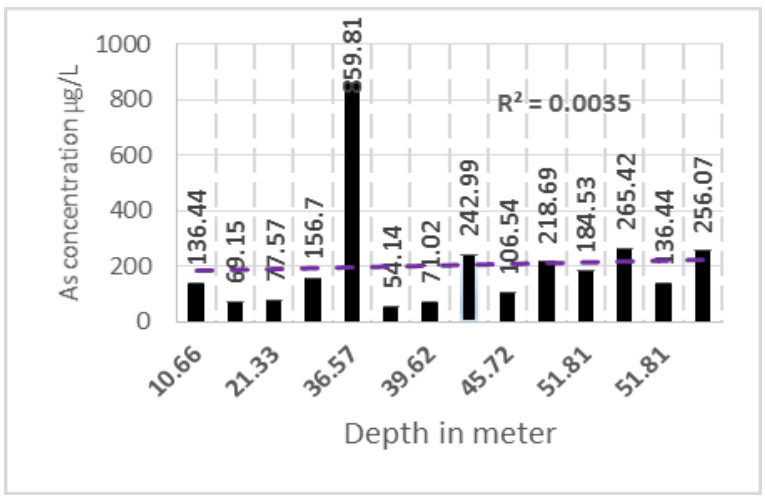


Arsenic found in soil either naturally occurring or from anthropogenic releases forms insoluble complexes with iron, aluminum, and magnesium oxides found in soil surfaces, and in this form, arsenic is relatively immobile. So, arsenic found higher amount in $15 \mathrm{~cm}$ and compared to $30 \mathrm{~cm}$ depth.

In aquatic systems, inorganic arsenic occurs primarily in two oxidation states, arsenic (V) and arsenic (III). Both forms generally co-exist, although arsenic (V) predominates under oxidizing conditions and arsenic (III) predominates under reducing conditions. Trivalent arsenic (III) is well absorbed through the skin of the body and is 60 times more toxic than pentavalent arsenic (V). Arsenic (III) oxidation state is predominating in ground water and arsenic (V) in the surface water. When ground water come out to surface, arsenic (III) will be autooxidation to form arsenic (V) [21]. It is clear that, when ground water is used for the purpose of irrigation, arsenic might have entered into soil as well as transfer to the food materials. When arsenic (III) come out from ground water, in presence of ambient oxygen or in presence of dissolve oxygen (DO), arsenic (III) is automatically changed to arsenic (V). Chemically arsenic (V) is more reactive than arsenic (III), so that arsenic (V) are absorbed by the soil, as a result, the chance of arsenic transfer did not occur from soil to plants. The concentration of arsenic at a depth of $15 \mathrm{~cm}$ is changed, much lower than that of $30 \mathrm{~cm}$ depth. Leaching property of arsenic in soil which is less than copper, sodium and potassium is reflected on the result. Long time is needed for leaching, arsenic from surface to ground level. It indicated that, the values of arsenic at $15 \mathrm{~cm}$ depth is higher than soil of 30 $\mathrm{cm}$ depth. The value of correlation coefficient $\left(R^{2}=0.904\right)$ is very much closer to 1 , it indicated that, arsenic concentration of in soil samples of $15 \mathrm{~cm}$ depth has good relationship. The composition of soil at Alampur village shows similar capacity to retain arsenic.

Table 2. The concentration of arsenic in soil samples collected from 15 and $30 \mathrm{~cm}$ depth at Alampur village

\begin{tabular}{ccc}
$\begin{array}{c}\text { Serial } \\
\text { Number }\end{array}$ & $\begin{array}{c}\text { Concentration of arsenic at } 15 \mathrm{~cm} \text { depth } \\
\mathrm{mg} / \mathrm{Kg}\end{array}$ & $\begin{array}{c}\text { Concentration of arsenic at } 30 \mathrm{~cm} \mathrm{depth} \\
\mathrm{mg} / \mathrm{Kg}\end{array}$ \\
1 & 1.175 & 0.1865 \\
2 & 1.808 & 0.9885 \\
3 & 1.996 & 2.3505 \\
4 & 2.313 & 1.3805 \\
5 & 2.537 & 2.3505 \\
6 & 3.973 & 1.0445 \\
7 & 3.97 & 1.884 \\
8 & 5.69 & 3.0035 \\
\hline
\end{tabular}

Figure 6. Concentration of arsenic at soil from $15 \mathrm{~cm}$ depth

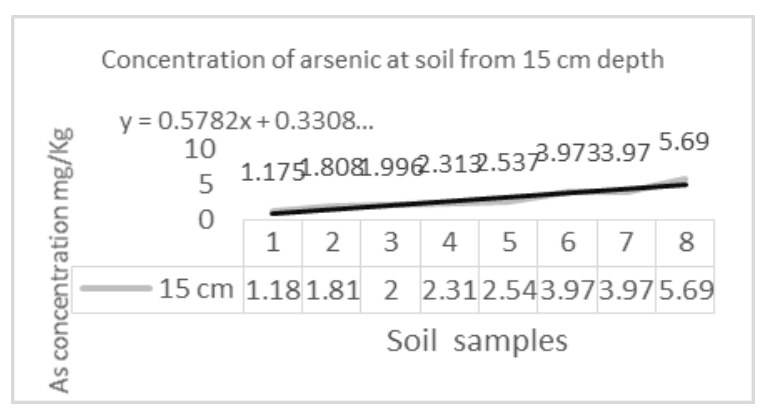


Figure 7. Concentration of arsenic at soil from $30 \mathrm{~cm}$ depth

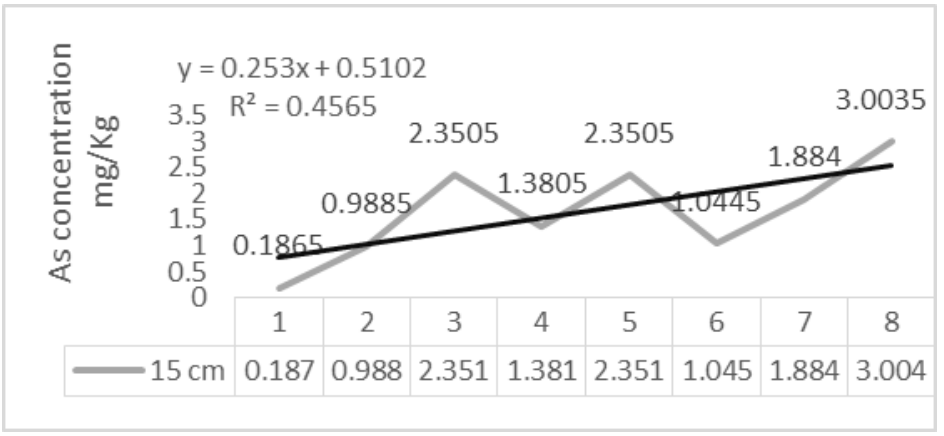

Figure 8. Variation of arsenic concentration at 15 and $30 \mathrm{~cm}$ depth soil samples

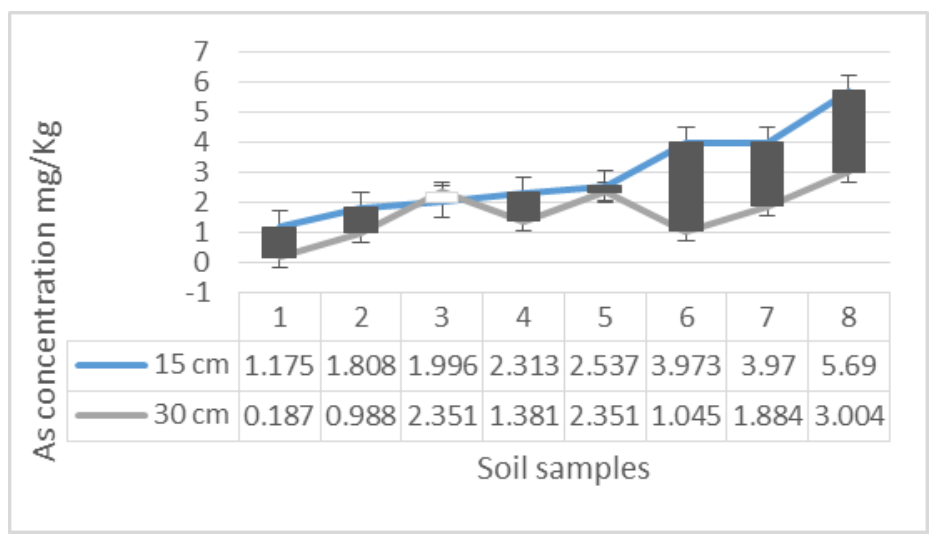

The value of correlation coefficient $\left(\mathrm{R}^{2}=0.4565\right) \quad$ indicated that, arsenic concentration in soil samples of $30 \mathrm{~cm}$ depth has poor relationship compared to the soil of $15 \mathrm{~cm}$ depth. This variation of arsenic might be depended on composition and structure of soil in 15 and $30 \mathrm{~cm}$ depth.

The plants which have roots going deeper into the soil layer have minor chance of arsenic up take. Consequently, less amount arsenic is found in these plants. Some plants have short life span and some are long life span. Short life span plants are less fortunate to take up arsenic from soil and some long life span plants take up arsenic because of having longer turns.

There is no epidemiological evidence of illness or cancer linkage the consumption the food materials from arsenic -rich soils. Despite the accumulation of arsenic in food materials attributable to growth on contaminated soils with elevated arsenic level, there was no significant statistical relationship between the concentration of arsenic in soil and that in food materials.
The Australian food hygiene limit of arsenic is $1 \mathrm{mg} / \mathrm{kg}$ [22]. The concentration of arsenic in variety of food collected from Alampur village is lower than the Australian food hygiene limit of arsenic. These values of arsenic in food materials that indicated the collected food samples (Table 3) is safe for eating.

Dantashak [Amaranthus gangeticus] is a long life span plant compared to the potato [Solanum tuberosum], arsenic is found in Dantashak at higher amount. The retention capacity for arsenic is higher at the soil of Alampur village. As a result, arsenic might not be propagated to the plants materials from the soil. The concentration tends gradually increased from potato to Dantashak, it means that the life cycle of potato to Datashak is gradually increasing with time.

The above-mentioned phenomenon is complex; the mechanism of arsenic uptake by the variety of food is not clearly unknown. It need further research arsenic in variety of food plants. In this above circumstance, variety of food is safe for arsenic but the tube 
well water is not safe for drinking at Alampur village. The concentration of arsenic all above tube well are contaminated with arsenic. Drinking safe water is very important for human life. Arsenic is a silent killer. It has been reported from the earlier researchers, some people have died due to arsenicosis at Alampur village of Meharpur district.

Table 3.The concentration of arsenic in variety of food collected from Alampur village

\begin{tabular}{ccc} 
Serial Number & Food Item & Concentration of arsenic mg/kg. \\
1 & Potato (Solanum tuberosum) & 0.029 \\
2 & Tomato (Lycopersicon esculentum) & 0.031 \\
3 & Banana (Musa acuminate) & 0.044 \\
4 & Lal Shak (Amaranthus gangeticus) & 0.073 \\
5 & Wheat (Triticum aestivum) & 0.102 \\
6 & Onion (Allium cepa) & 0.154 \\
7 & Arum (Arum maculatum) & 0.175 \\
8 & Dantashak (Amaranthus lividus) & 0.202 \\
\hline
\end{tabular}

Figure 9. Arsenic concentration in variety food

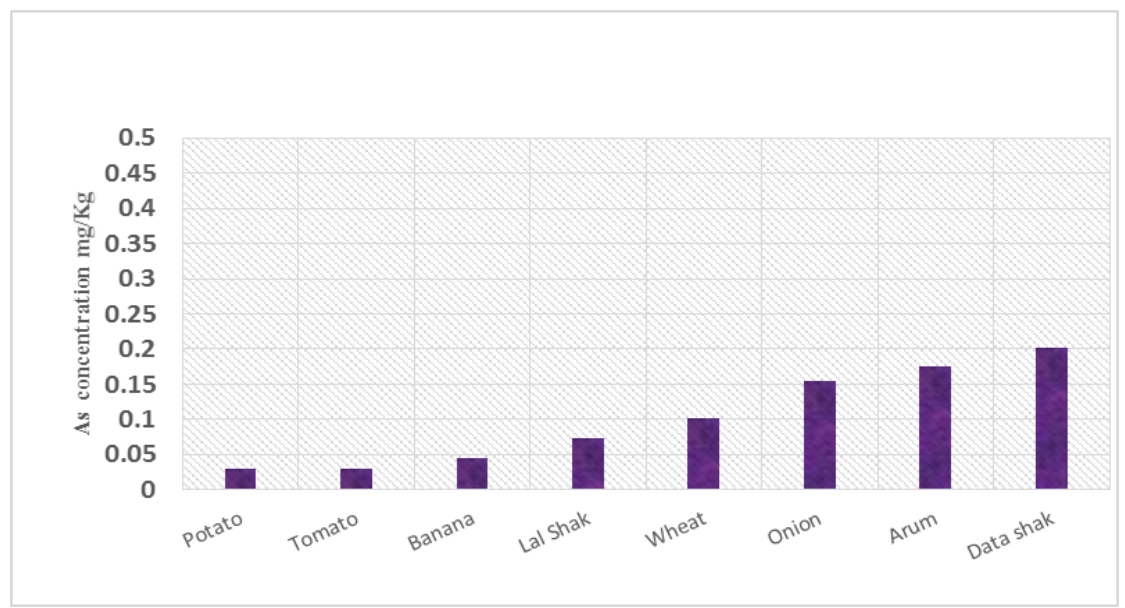

\section{Conclusion}

Groundwater is generally more vulnerable to arsenic contamination than surface waters because of the interaction of groundwater with aquifer minerals and the increased potential in aquifers for the generation of the physicochemical conditions favorable for arsenic release. However, the concentration of arsenic depends not only on depth of the aquifers but also the geological and geophysical conditions of aquifer's environment. The depth of the aquifers has increasing linearity from $10.66 \mathrm{~m}$ to $54.86 \mathrm{~m}$, as the ratio but the concentration of arsenic is not decreasing linearity of the tube well of Alampur village. The depth of the aquifers has increasing linearity from $10.66 \mathrm{~m}$ to $54.86 \mathrm{~m}$. As a ratio of concentration with depth, the concentration of arsenic did not obey a linearity with depth of aquifer. The concentration of arsenic in soil samples lie with the range of limit values $(5 \mathrm{mg} / \mathrm{Kg})$. The concentration of arsenic was within of the values for soil samples ( $5 \mathrm{mg} / \mathrm{Kg}$ ). It indicated that, less chance of arsenic is in food materials from soil. Although, the tube well water of 
Alampur village contaminated with arsenic. The villagers of Alampur should be drinking arsenic free water from any other alternative sources. However, arsenic content of in food materials within the limit of Australian food hygiene $(1.0 \mathrm{mg} / \mathrm{Kg})$.

BGS=British Geological Survey of Bangladesh DPHE=Department of Public Health of Engineering

JICA=Japan International; Cooperation

Agency

STW=Shallow Tube well

GPS=Global Positioning System

\section{Acknowledgement}

The authors highly acknowledge Independent University Bangladesh (IUB), Department of Environmental Science, for financial support to carry out this research work. And also, acknowledge Global Environment Consultant Limited (GECL) for laboratory support in order to complete the research work.

\section{Disclosure statement}

No potential conflict of interest was reported by the authors.

\section{ORCID}

M. Jamilur Rahman (D): 0000-0002-4639-5680 M. N. E A. Siddique (D): 0000-0002-2077-9491 H. Hamidi D: 0000-0002-5019-8591

\section{References}

[1] M. Zimmermann, K.F. Glombitza, B. Rothenberger, Disaster Risk Reduction Programme for Bangladesh 2010-2012, Published by the Swiss Agency for Development and Cooperation (SDC) Directorate of Humanitarian Aid and SHA, CH-3003 Bern.

[2] U. Münster, S. Satsuka, G. Cedrelöf, Asian Environments Connections across Borders,
Landscapes, and Times, LudwigMaximilians Universität, Germany, 2014.

[3] G.E. Shephard, R.D. Müller, L. Liu, M. Gurnis, Nature Geoscience, 2010, 3, 87075.

[4] S. Murcott, Arsenic contamination in the world, IWA publishing, UK, 2012.

[5] Karim M.M., Komori Y. and Alam M., J. Environ. Chem., 1997, 7, 783-792.

[6] M.H. Ali, A. Akter, Int. J. Environ. Sci. Technol., 2011, 8, 433-443.

[7] M.M. Hussain, S.K.M. Abdullah, Geological Setting of the Areas of Arsenic Safe Aquifers, Groundwater Task Force, Geological Survey of Bangladesh, Govt. of Bangladesh, 2001.

[8] D. Das, G. Samanta, B.K. Mandal, T.R. Chowdhury, C.R. Chanda, P.P. Chowdhury, G.K. Basu, D. Chakraborti, Environ. Geochem. Health, 1996, 18, 5-15.

[9] S.M. Imamul Huq, J.C. Joardar, S. Parevin, R. Correll, R. Naidu, J. Health popul. Nutr., 2006, 24, 305-306.

[10] M.F. Hughes, B.D. Beck, Y. Che, A.S. Lewis, D.J. Thomas, Toxicol. Sci., 2011, 123, 305332.

[11] A.H. Welch, D.B. Westjohn, D.R. Helsel, R.B. Wanty, Ground Water, 2000, 38, 589-604.

[12] A.M. Albright, E.L. Saari, J.M. Leaver, E. Saari, S.M. Dillon, Leaching of Metals into Groundwater-Understanding the Causes and an Evaluation of Remedial Approaches, Bachelor of Science thesis, Worcester Polytechnic Institute, 2012, p 8.

[13] D.A. Ahsan, T.A. Del Valls, Int. J. Environ. Res., 2011, 5, 627-638.

[14] A. Heikens, Arsenic contamination of irrigation water, soil and crops in Bangladesh: Risk implications for sustainable agriculture and food safety in Asia, published by food and agriculture organization of the United Nations Regional office for Asia and the Pacific, Bangkok, 2006. 
[15] H. Garelick, H. Jones, A. Dybowska, E. Valsami-Jones, Rev. Environ. Contam. Toxicol., 2008, 197, 17-60.

[16] P. Ravenscroft, H. Brammer, K. Richards, Arsenic pollution-a global synthesis, Wiley-Blackwell, UK, 2009.

[17] B. Ahmed, Arsenic in food chain through irrigation water-soil-crop pathway; Risk assessment for sustainable agriculture of Bangladesh. An MSc thesis submitted to Department of Water and Environment, Swedish University of Agricultural Science (SLU), Uppsala, Sweden, 2009.

[18] P. Bhattacharya, K.M. Ahmed, M.A. Hasan, S. Broms, J. Fogelström, G. Jacks, $\mathrm{O}$. Sracek, M. von Brömssen, J. Routh, Mobility of arsenic in groundwater in a part of Brahmanbaria district, NE Bangladesh. Managing arsenic in the environment: from soil to human health,
CSIRO Publishing, Melbourne, Australia, 2006, pp. 255-271.

[19] H.K. Das, D.A. Chowdhury, S. Rahman, M.M. Obaidullah, P. Sengupta, F. Islam, Environ. Int., 2002, 30, 383-387.

[20] F.K. Ferdousi, M.A. Rahman, M.N.A. Siddique, A.M.S. Alam, Environmental Impact of Arsenic on water, soil and food chain in Hajigonj, Bangladesh: A case study, Dhaka Univ. J. Sci. 2008, 56, 107111.

[21] T. Missimer, C. Teaf, W. Beeson, R. Maliva, J. Woolschlager, D. Covert, Int. J. Environ. Res. Public Health, 2018, 15, 2278.

[22] J. S. Jean, J. Bundschuh, P. Bhattacharya, Arsenic in Geosphere and Human Diseases; Arsenic 2010: Proceedings of the Third International Congress on Arsenic in the Environment (As 2010), CRC press, 2010.

How to cite this manuscript: T. A. Haque, M. Tabassum, Md J. Rahman, M. N. E A. Siddique, M. G. Mostafa, M. A. Khalaque, Z. Abedine, H. Hamidi, Environmental Analysis of Arsenic in Water, Soil and Food Materials from Highly Contaminated Area of Alampur Village, Amjhupi Union, Meherpur, Adv. I. Chem. A, 2020, 3(2), 181-191. 